\title{
José de Alencar: o povo, a língua e a literatura
}

\author{
José de Alencar: the people, the language and literature
}

\author{
Manoel Carlos Fonseca de Alencar \\ Universidade Estadual do Ceará (UECE), Fortaleza, CE, Brasil
}

RESUMO: O presente artigo analisa o pensamento do escritor José de Alencar quanto à originalidade da literatura brasileira, servindo-se do ensaio $O$ nosso cancioneiro e dos paratextos que acompanham os romances Iracema e Sonhos d'ouro. No sentido de pensar essa originalidade, o autor teceu um conjunto de observaçôes, umas de ordem linguística e outras sobre a formação do povo brasileiro. Do ponto de vista linguístico, num primeiro momento, Alencar levou em conta a língua indígena, considerando o aproveitamento de seus vocábulos na narrativa literária. Depois de Iracema, contudo, a sua atenção voltou-se ao que denominou "língua falada pelo povo", entrevista em dois poemas populares analisadosanalisadas em O nosso cancioneiro. Quanto à formação do povo brasileiro, processo que no prefácio de Sonhos d'ouro o autor correlaciona às fases da literatura, a ênfase recai sobre a adaptação dos portugueses aos trópicos, muito mais do que ponderações relativas à miscigenação. Procura-se demonstrar que, embora considerasse a importância da língua indígena e da fala do povo para a singularidade da literatura brasileira. Alencar as tinha como inferiores, tornando elitista e excludente o seu projeto de homogeneização da língua e da literatura.

PALAVRAS-CHAVE: História. Literatura. Língua brasileira. José de Alencar.

ABSTRACT: This article analyzes the thought of the writer José de Alencar regarding the originality of Brazilian literature, using the essay O nosso cancioneiro and the set of textual elements that accompany the novels Iracema and Sonhos d'ouro. In the sense of thinking this originality the author made observations related to both aspects: linguistic and focusing the formation of the Brazilian people. From the linguistic point of view, at first, Alencar took into account the indigenous language, considering the use of his words in the literary narrative. After Iracema, however, his attention was drawn to what he called "the language spoken by the people", present in two popular poems from O nosso cancioneiro which were analysed. Regarding the formation of the Brazilian people, a process that in the preface to Sonhos d'ouro the author correlates with the phases of literature, the emphasis is on the adaptation of the Portuguese to the tropics, much more than considerations about miscegenation. It aims to demonstrate that although José de Alencar considered the importance of the native language and the speech people to the singularity of the Brazilian Literature, the author had them like inferiors, made elitist and excluding its project of homogenization of the language and the literature.

KEYWORDS: History. Literature. Brazilian language. José de Alencar.

\footnotetext{
* Professor da Universidade Estadual do Ceará (UECE), Fortaleza, CE, Brasil. Doutor em História pela Universidade Federal de Minas Gerais (UFMG).E-mail: manoel.alencar@uece.br. https://orcid.org/0000-0003-0159-7649.
} 


\section{Introdução}

José de Alencar é um dos escritores mais estudados do Brasil. Os ensaios, artigos e teses são muitos. Os estudos remontam ao período em que o próprio romancista publicou suas obras. "Iracema", por exemplo, gerou, logo depois de vir a lume, muitos comentários e críticas, que suscitaram, inclusive, respostas do próprio Alencar. As polêmicas eram de variada ordem: linguísticas, literárias, teorias de formação do povo brasileiro e outras mais. São ilustrativas dessas polêmicas, as encetadas por José de Alencar contra Pinheiro Chagas e as conhecidas Cartas a Cincinato, escritas por Franklin Távora (Borges, 2010; Ribeiro, 2008). Silvio Romero foi outro escritor cuja crítica realista centrou-se boa parte em combater o Romantismo. Caso uma nova corrente literária quisesse se afirmar, deveria centrar fogo naquela que a antecedeu. $\mathrm{O}$ alvo principal foi Alencar, já que este era um dos mais renomados escritores românticos da época

As contendas em torno da obra de José de Alencar estenderam-se por todo século XX. Por vezes, a crítica era direcionada à forma, detratando Alencar e o Romantismo brasileiro por sua pouca consistência. Neste caso, alguns críticos apontavam a descrição da realidade brasileira como ponto positivo, a ser considerado na avaliação das qualidades do romancista. Antônio Cândido, por exemplo, ainda que apresente muitas ressalvas ao Romantismo brasileiro, pondera sobre a importância de seu realismo e sentimento nacional para a formação da literatura nacional (Cândido, 1997). Em alguns casos, é o próprio leitor que é menosprezado, pois era tido como infantil, apreciador de folhetins adocicados, de segunda categoria. A literatura de Alencar seria vista com ressalvas, mas corresponderia ao seu leitor e ao próprio estágio de formação do sistema literário, ou mesmo à evolução da sociedade brasileira. (Boechat, 2003)

O indianismo de José de Alencar provocou também intensos debates. Em verdade, as controvérsias e paradoxos em torno da figura do índio como representante da nacionalidade encontram-se presentes desde o processo de Independência, e não deixaram de estar conectadas com uma perspectiva das elites imperiais relativa ao lugar do indígena na sociedade brasileira. O indianismo, portanto, manteve estreita relação com o indigenismo; um programa literário interligava-se com um projeto político (Treece, 2008). O debate em torno da importância do indígena para a caracterização da nacionalidade tomou, por vezes, feição internacional. O francês Fernand Denis, ainda na década de 1820, salientava ser imprescindível o aproveitamento das tradiçóes indígenas para a nacionalização da literatura brasileira. (Ribeiro, 1997)

De acordo com Trecee, o Indianismo pode ser dividido em dois momentos. O primeiro subsiste até a década de 1850 e se caracteriza por uma escrita denunciativa da colonização portuguesa, cuja consequência foi dramática para as populações indígenas, africanas, mestiças e pobres. Ilustrativa dessa fase é a obra de Gonçalves Dias, permeada pelo sentimento de exílio e tragicidade. Um traço que pode ser encontrado tanto na escrita como na vida mestiça do poeta maranhense.

No segundo momento, contexto de certa estabilidade na ordem imperial, o Indianismo foi marcado por um imaginário de conciliação das etnias, que, no nível da narrativa, figura uma harmonia social (Trecee, 2008). O amor de Peri e Ceci, no O Guarani (1858) é alegoria dessa perspectiva conciliativa, culminando, em Iracema (1865), com o enlace do português Martin e a índia Iracema (Ribeiro, 2005). Nos paratextos deste último romance, José de Alencar elaborou uma profunda reflexão sobre o modo como devem ser incorporadas as tradições indígenas à literatura, com destaque para a língua nativa. Este artigo analisa essa questão, inclusive as contendas em torno dela. 
Essas polêmicas tem seu culminar, em 1868, com o ensaio que discorreu sobre assuntos linguísticos: o pós-escrito de Iracema (1870). Desde então, a questão indígena ocupou um lugar secundário no programa de nacionalização da literatura de José de Alencar, voltando-se o autor ao que denominou língua "falada pelos nossos pais", como está bem expresso no prefácio de "Sonhos D'ouro" (1872) e no ensaio de 1874, denominado Questão filológica (Borges, 2006). Nas cartas a Joaquim Serra, intituladas $\mathrm{O}$ nosso cancioneiro, como veremos, Alencar analisou duas poesias populares do Ceará, e daí extraiu conclusóes de ordem linguísticas, defendendo a independência literatura brasileira.

O nacionalismo subjaz, portanto, a criação de Alencar e as críticas, ou parte significativa delas, que lhes foram endereçadas. O empenho do autor, desde a sua estreia no campo da literatura, com as Cartas sobre a Confederação dos Tamaios (1856), foi o de conceber uma escrita original, tipicamente nacional. Ou melhor, o romancista pretendia criar uma narrativa que representasse o país, em sua diversidade espacial e de cores - inclusive a variedade étnica.

Essa representação criada pelo autor foi motivo de muitas controvérsias. Nesse sentido, foram variadas as indagações dos estudiosos, cuja questão principal a ser respondida era se suas narrativas se constituíam nacionais ou importadas. Para Roberto Schwarcz, eram importadas; Machado de Assis é que teria posto as ideias no lugar, ao descortinar as contradiçôes do liberalismo em um país em que a sociedade se organizava com base no favoritismo (Schwacz, 1992). Ou elas estariam no “entrelugar”? (Santiago, 1982). Quanto aos indígenas, por exemplo, Maria Cecília Moraes Pinto defende que em Alencar a figura do indígena é nacional, acentuando a sua diferença em relação ao índio de Chateaubriand. (Morais Pinto, 1995). Haroldo Campos, no começo da década 1980, apontou a proposta linguística inovadora de Alencar, precedendo a Semana de Arte Moderna de 1822. Segundo ele, o escritor criou uma escrita selvagem e nacional, no seu modo de processar a língua portuguesa e indígena e incorporá-las ao texto ficcional. (Campos, 1990)

Neste artigo, investiguei as propostas linguísticas e literárias de Alencar, tomando como referência alguns de seus paratextos e preocupando-me em percebê-las conjuntamente com a sua concepção histórica. Com Raymond Williams (1989), procurei situar a questão em perspectiva histórica, ou melhor, compreender que as propostas de incorporação das tradições populares (mestiças, africanas, indígenas e portuguesas) à literatura passam por mudanças, determinadas pelo processo histórico no qual estão inseridas. Por fim, com base em Walter Mignolo (2003), visei entender a óptica colonialista de José de Alencar em relação ao povo, com destaque para a língua e a literatura.

\section{A nação brasileira e língua portuguesa no século XIX}

Em termos objetivos, a língua dificilmente pode ser tomada como um critério para definir nação, a não ser como invenção de uma elite letrada, no processo de homogeneização cultural, inerente à formação das nações modernas. A língua não é, contudo, criação meramente artificial (HOBSBAWN, 1990). No caso de José de Alencar, percebe-se que o seu projeto de padronização de uma "língua brasileira" ${ }^{2}$ é, em princípio, ancorado na língua indígena e, posteriormente, em uma língua falada pelo povo, proveniente da poesia popular, como mostram suas muitas contendas linguísticas.

A imagem de uma nação unificada foi geralmente acompanhada de campanhas de alfabetização do povo no Brasil e na América Latina no século XIX. A necessidade de ampla campanha de alfabetização, com intuito de educar e civilizar o povo, é a tônica da maior parte dos escritores e ensaístas brasileiros, sobretudo dos republicanos, que vinculavam educação e cidadania. 
No Ceará, por exemplo, já em 1874, os escritores da denominada Academia Francesa fundaram a Escola Popular, em que promoviam palestras abertas ao povo. Alguns conhecidos escritores brasileiros proferiram palestras nessa escola. Entre eles podemos citar: Capistrano de Abreu, Araripe Júnior e Senador Pompeu.

José Veríssimo é paradigmático em se tratando de um projeto de educação nacional com vistas ao progresso e à civilização no Brasil. Não foi a alfabetização, entretanto, o fator determinante para a integração linguística das várias populações à língua hegemônica, pois os índices escolares eram ínfimos. As populações indígenas e africanas das Américas foram historicamente integradas à língua hegemônica por outros meios, decorrentes de um longo processo de colonização (CARVALHO, 1998; COSTA, 2004).

No esforço de unificação política da nação, uma língua foi padronizada para usos literários e administrativos (HOBSBAWN, 1990; MIGNOLO, 2003). No caso do Brasil, esses projetos de definição da "língua brasileira" descartaram as línguas indígenas e africanas como dignas de se constituírem como língua oficial do país, pois os letrados as consideravam primitivas ou bárbaras. Estas línguas deveriam ser dissolvidas na língua nacional, com o aproveitamento de alguns vocábulos, expressões e dicções, que corroborariam a autenticidade do português brasileiro. ${ }^{3}$

No período em estudo, a língua indígena foi intensamente explorada por muitos intelectuais como fonte linguística conformadora da nacionalidade literária. Os periódicos científicos e literários da época estampavam inúmeros estudos da língua indígena, pontuando sua centralidade para a independência linguística (KADAMA, 2009). Na poesia e na prosa de ficção, era comum encontrar muitos vocábulos salpicados, comumente acompanhados de um glossário, trazendo a tradução dos termos indígenas para o português. São os casos, por exemplo, dos romances $O$ Guarani (1857) e Iracema (1865), de José de Alencar, e do poema indianista Porangaba (1861), de Juvenal Galeno. Como sabemos, o indianismo foi a mais importante ideologia do Estado Imperial e os escritores românticos incorporaram largamente as suas lendas, mitos e línguas à imaginação nacional (ALONSO, 2002).

No que diz respeito aos afrodescendentes é visível uma exclusão, se não de completo silenciamento de sua cultura. Não havia ensaios, nas décadas de 1860 e 1870, cujo interesse fosse exclusivamente as línguas africanas. José de Alencar, considerado praticamente um dos inventores da literatura nacional, não escreveu um ensaio cujo interesse fosse unicamente a língua dos negros, ainda que tenha reconhecido a sua contribuição para a formação do idioma brasileiro. Nos anos de 1880, Silvio Romero denunciou esse sepulcral silêncio, mas a custo de considerar as línguas africanas bárbaras e incivilizadas. Com o Modernismo, o problema teve grande destaque e a fala dos africanos no Brasil foi incorporada como fator importante da língua. Gilberto Freire observava os costumes dos diminutivos e da fala meio amolengada como traços de uma herança africana que não nos deveria envergonhar.

A língua foi um elemento fundante da imaginação nacional. Como no século XIX a literatura se mostrava aos escritores como espelho da nação, sendo capaz de representar o ser nacional em seus diversos aspectos, a questão da língua assumiu um papel proeminente. Conforme aponta Walter Mignolo:

Uma das armas poderosas para a construção de comunidades imaginadas homogêneas foi a crença numa língua nacional, ligada a uma literatura nacional, que contribuísse, no domínio da língua, para a cultura nacional. Ademais, a cumplicidade entre língua, literatura, cultura e nação relacionava-se também a ordem geopolítica e as fronteiras geográficas. Língua e literatura faziam parte de uma ideologia de Estado, apoiada por seus intelectuais orgânicos. (MIGNOLO, 2003, p. 299) 
José de Alencar, por exemplo, ligava a independência do país, em termos culturais, à determinação de uma "língua" e de uma literatura que fossem distintas da Metrópole. Daí por que, na definição de um idioma brasileiro, ele propôs o aproveitamento das línguas indígenas e da língua aclimatada no país como critério de diferenciação linguística.

Como assinala Benedict Anderson, desde o século XVIII, assiste-se na Europa à predominância de escritos nas línguas vernáculas, em detrimento do latim. Os estudos linguísticos se multiplicavam e serviam como base de uma unidade simbólica nacional. Não casualmente, essa "[...] foi a idade de ouro dos lexicógrafos, gramáticos, filólogos e literatos do vernáculo" (ANDERSON, 2008, p. 112). Os critérios de escolha da língua ou do dialeto que serviriam de modelo para a constituição de uma língua nacional eram variados. Geralmente a língua que se impôs como nacional foi aquela falada por uma intelectualidade minoritária e combativa, que orbitava em torno do poder. A língua nunca deixou, contudo, de ser um construto semiartificial: seja porque correspondia, majoritariamente, apenas a uma das tantas línguas ou dos dialetos falados, ou porque tomou a forma de um mosaico, tentando privilegiar certa diversidade linguística do território nacional (COLETTI, 2009).

José de Alencar, nos inúmeros debates que encetou, dá a dimensão dos pontos suscitados pelas elites letradas em torno da língua. No seu entendimento, a independência política do país deveria se desdobrar também em uma independência cultural. Como a língua oficial do Império era a língua portuguesa e a nação deveria ser independente e diversa da antiga Metrópole, a questão fundamental do programa alencariano foi determinar a diferença do "idioma brasileiro" de sua matriz europeia. No final do seu ensaio $O$ nosso cancioneiro, cuja questão central era averiguar a contribuição da poesia popular na nacionalização da língua, o autor enfatizou a associação entre política e língua, em seu projeto de "naturalização da literatura". O ensaio visava a questionar "uns profundíssimos filólogos" portugueses que "[...] negam a nós brasileiros, o direito de legislar sobre a língua que falamos”. Assim,

[...] depois da independência, se não antes, começamos a balbuciar a nossa literatura, pagamos, como era natural, o tributo à imitação, depois entramos em sentir em nós a alma brasileira, e a vazá-la nos escritos, com a linguagem que aprendemos de nossos pais. Prosseguimos com a nossa senda, quando em Portugal principiou a cruzada contra a nossa embrionária e frágil literatura, a ponto de negar-nos até uma individualidade própria. Não era engenhoso, e não era justo. (ALENCAR, 1960, p. 982)

Descartada, portanto, por José de Alencar, a possibilidade de as línguas indígenas e africanas serem consideradas como a língua nacional, interessava-lhe manter a língua portuguesa, mas a diferenciando de sua matriz; ou melhor, abrasileirar o português de Portugal. Nesse sentido, o autor elaborou uma argumentação tipicamente romântica a respeito do desenvolvimento da língua e de sua centralidade para a constituição de uma literatura nacional. Foram os românticos os contestadores dos padróes clássicos, em razão dos seus paradigmas formalistas e universalistas, e defensores de que a língua deveria ser considerada como fator dinâmico no desenvolvimento da personalidade dos povos. (SALIBA, 2002)

Essas ideias subsidiaram os vários movimentos culturais europeus que pregavam a língua e a literatura como fatores responsáveis pela singularidade das naçôes, dado que foram deslocados os critérios valorativos da literatura da imitação das formas clássicas para a capacidade do artista de expressar a natureza e a cultura em que estava enraizado. O escritor deveria partir da língua falada pelo povo, e não das formas clássicas, para a criação literária. 
$\mathrm{Na}$ Europa, a ênfase foi conferida ao uso das línguas vernáculas em detrimento do latim e, em determinados casos, em prejuízo das línguas estrangeiras, como a francesa. A Alemanha, por exemplo, enquadra-se no segundo caso, pois lá uma classe média letrada defendeu o uso do alemão em oposição ao francês, que era escrito e falado pela nobreza. ${ }^{4}$ No caso do Brasil, onde a língua da Metrópole era a das elites letradas, não se tratava propriamente de negar a sua matriz em prol de outra língua, como no caso das línguas indígenas e africanas, mas encontrar um ponto médio (COLETTI, 2009) entre a língua portuguesa de Portugal e a língua portuguesa falada no Brasil - que era, sem dúvida, diferente.

Nas reflexões alencarianas sobre a língua, é notável uma transição de pensamento. Até Iracema, o autor tinha como proposta a constituição de uma literatura nacional com base no aproveitamento da língua de uma "raça extinta", o indígena; depois de Iracema, o escritor passou a reportar-se a uma língua falada pelo povo, enxergando nesta, inclusive, um idioma novo. As análises linguísticas do autor eram ancoradas em reflexões históricas que davam conta da formação do povo brasileiro, o que definiu a sua escolha da lingua da literatura brasileira.

\section{A formação do povo, a língua e a literatura: a perspectiva histórica de Jose de Alencar}

Alencar formulou com maestria, em suas cartas, notas, prólogos e posfácios, uma sólida explicação sobre como a literatura poderia se referenciar na língua falada pelo povo e qual seria exatamente esse povo. Em Benção Paterna, prefácio do romance Sonhos d'ouro (1872), desenvolveu o argumento para se entender o que denominou "período orgânico" da literatura. Nesse sentido, analisou as fases históricas da literatura, levando em conta a contribuição dos portugueses e dos indígenas na formação da cultura brasileira, para então deduzir qual seria a língua mais adequada para a constituição de uma língua literária nacional. Em outras palavras, Alencar demonstrou o que necessariamente significava essa língua histórica na conformação de um "[...] eu próprio, que resiste ao prurido da imitação" (ALENCAR, 1872, p. XIV).

O romancista dividiu em três fases o período orgânico da literatura nacional: primitiva, histórica e "infância da literatura”. Nesse sentido, vale observar, primeiramente, a diferença entre o desenvolvimento da língua e da literatura na perspectiva de José de Alencar. Segundo ele, no princípio, não havia nem uma língua nem uma literatura nacional. A língua passou por um processo de aclimatação, mas não gestou, de logo, uma literatura nacional. Nos escritores anteriores à independência política, já se podia vislumbrar essa aclimatação da língua, mas eles não escreviam uma literatura brasileira, dado serem portugueses nos trópicos e escreverem obedecendo às normas linguísticas portuguesas. Foi só a independência política que ensejou o nascimento de uma literatura própria para o país. Desta forma, o período no qual o autor se situava era no terceiro, que são os "começos" da literatura nacional. Desde aí, ele próprio se considerava parte do longo processo de formação da literatura, que estava em sua "florescência", e propunha-se a definir o que seria importante para o desenvolvimento da singularidade brasileira.

A primeira fase, a primitiva, era composta por "lendas e mitos, da terra selvagem e conquistada”. Nesse período, não se podia falar nem de uma língua nem de uma literatura brasileiras. Elas se resumiam às tradiçóes de Portugal, que Alencar metaforizou com a imagem do "[...] filho a quem a mãe acalenta no berço com as canções da pátria, que abandonou” (ALENCAR, 1872, p. XIII). 
O romance Iracema aborda essa fase, que era o período inaugural, o da "infância" dos povos, das origens dos países, no qual a língua portuguesa não havia ainda se aclimatado aos trópicos. Segundo anota, é uma idade cheia de "santidade e enlevo", período em que os portugueses que aqui chegaram apenas "veneravam” a "terra pátria”, a "mãe fecunda”, e não viam no Brasil outra coisa senão a terra em que pisavam. Martin é a alegoria do português que nenhum laço mantém com a terra. Durante todo o romance, tem seus sentimentos e sonhos voltados para o além-mar. Tal fato causa, inclusive, certa frustração em Iracema, pois tem que suportar a ideia de seu amado viver triste, com os pensamentos em uma mulher branca, que se espreitava no horizonte. Ou seja, os primeiros colonizadores tinham o seu olhar voltado para o atlântico, desconsiderando a natureza e as tradições indígenas brasileiras.

A segunda fase, a histórica, apesar de não bem definida no prefácio, compreende os anos que vão dos séculos XVII e XVIII até a independência política. A língua brasileira teve seu desenvolvimento nesse período, que "[...] representa o consórcio do povo invasor com a terra americana, que dele recebia a cultura, e lhe retribuía nos eflúvios de sua natureza virgem e nas reverberaçóes de uma natureza esplendida” (ALENCAR, 1872, p. XIII). Nas poéticas palavras de Alencar:

Ao conchego desta pujante criação, a tempera se apura, toma alas a fantasia, a linguagem se impregna de módulos mais suaves; ornam-se outros costumes, e uma existência nova, pautada por diverso clima, vai surgindo. É a gestação lenta do povo americano, que devia sair da estirpe lusa, para continuar no novo mundo as gloriosas tradiçóes de seu progenitor. Esse período colonial terminou com a independência. (ALENCAR, 1872, p. XIII)

Note-se que Alencar criou uma antítese entre natureza e cultura. Os portugueses, aqui chegando, encontraram uma terra virgem, uma "pujante criação", com a qual estabeleceram uma troca: trouxeram cultura e receberam dos trópicos uma natureza exuberante, que lhe propiciaram a formação de uma civilização, com uma língua diferente e outros costumes. Os romances O guarani (1857) e Minas de prata (1865) narram este período. O guaranié ambientado às margens do rio Paquequer, um afluente do rio Paraíba, e transcorre no começo do século XVII. Minas de Prata, por sua vez, toma como cenário a Bahia desse mesmo período. Pode-se também situar aí OSertanejo, escrito depois do prefácio de Sonhos d'Ouro (1872). O romance possui todas as características dos romances situados nessa fase, mas em um período bem adiantado, pois os acontecimentos se desenrolam na metade do século XVIII, nos sertões cearenses.

$\mathrm{Na}$ terceira fase, posterior à independência, de acordo com Alencar, já teríamos uma língua suficientemente aclimatada, a ponto de ele se reportar à língua falada no Brasil como um idioma novo. Com base nesse idioma, os escritores brasileiros deveriam constituir uma literatura genuína. Portanto, ele próprio faz parte dessa fase, que é a infância da literatura nacional. No concernente a essa, ele escreveu os seus chamados romances urbanos, que são $A$ viuvinha (1860) e Cinco minutos (1860), Luciola (1862), Diva (1864), A pata da gazela (1870), Senhora (1875) - que não está citado em Benção Paterna, pois foi escrito posteriormente ao prefácio - e o próprio romance Sonbos d'Ouro (1872). Alguns desses romances foram alvo de intensas críticas da parte de escritores contemporâneos a Alencar, que o acusavam do uso excessivo de estrangeirismos e galicismos. Alencar retrucou:

Tachar estes livros de confeição estrangeira, é, relevem os críticos, não conhecer a fisionomia da sociedade fluminense, - que aí está a faceirar-se pelas salas e ruas com atavios parisienses, falando a algemia universal, que é a língua do progresso, jargão erriçado de termos franceses, 
ingleses, italianos e agora também, alemães. Como se há de tirar a fotografia desta sociedade, sem lhe copiar as feições? Querem os tais arqueólogos literários, que se deite sobre a realidade uma crosta de classicismo, como se faz com os monumentos e os quadros para dar-lhes o tom do merecimento do antigo? (ALENCAR, 1872, p. XV)

O romancista justificou o uso dos muitos estrangeirismos em seus romances urbanos com o argumento de que estaria tirando uma fotografia da sociedade cosmopolita e universal das cidades, em especial, da Corte. Nesse espaço, portanto, o autor identificou poucos traços, seja de costumes ou linguísticos, que possibilitassem a constituição de uma literatura de "cor local”. Os romances urbanos têm um papel de denúncia militante contra a invasão dos novos valores da civilização que o escritor considerava condenáveis. Senhora, um dos últimos romances urbanos de Alencar, traz essa crítica de forma magistral. Nele, Alencar, como bom romântico, denunciou o poder dissolvente do dinheiro sobre as relações humanas, a artificialidade reinante na sociedade civilizada e o ímpeto, entre os habitantes da Corte, de imitar tudo o que vinha de fora.

Enquadram-se também nessa fase os romances ambientados, não na Corte, mas em suas proximidades. Resultavam do processo, observado por José de Alencar, de descaracterização da cultura brasileira. Não são romances históricos, como salientou o autor, pois suas ações aconteciam em tempo recente, com base no qual ele próprio vivenciou as transformações que se passavam com a língua, os costumes, os mitos, as lendas, enfim, as mudanças no imaginário, decorrentes da integração do país à modernidade. Em suas palavras, o

Tronco do Ipê, o Til e o Gaúcho, vieram dali; embora, no primeiro, sobretudo, se note já, devido à proximidade da corte, e à data mais recente, a influência da nova cidade, que de dia em dia se modifica, e se repassa do espírito forasteiro. Nos grandes focos, especialmente na corte, a sociedade tem a fisionomia indecisa, vaga e múltipla, tão natural à idade da adolescência. (ALENCAR, 1872, p. XV)

Desta forma, a literatura, que principiava sua independência, teria de servir-se da língua historicamente desenvolvida em solo americano para conquistar sua autonomia cultural, revelando-se como original e distinta. Assim, faz-se necessário compreender o modo como Alencar procedeu à incorporação das línguas, no caso, as indígenas e a portuguesa, na definição de uma língua e literatura nacionais ou, dito de outro modo, como as culturas populares foram transculturadas no nível da narrativa alencariana. ${ }^{5}$ Não há como pensar a mesma análise para as línguas africanas, pois o autor não lhes dedicou estudos mais detalhados.

\section{A língua indígena e a literatura nacional}

De acordo com Alencar, na fase primitiva não existia literatura nacional, e sim apenas as línguas portuguesa e indígena. A língua indígena, na concepção do romancista, não poderia ser alçada à condição de língua nacional, pois, como pensava, apesar de sua singeleza, não era uma língua civilizada. Quando o autor fez referência aos indígenas, ele os concebeu como seres naturais e não culturais. Assim como os índios, são a fauna, a flora e o clima tropical. Todos esses elementos constituíam o ambiente que propiciou a aclimatação do português no Brasil. 
Ainda que concebendo a língua indígena como selvagem, Alencar propôs se servir dela. Na sua Carta a Jaguaribe, um posfácio a Iracema (1865), ele teceu um conjunto de consideraçóes sobre a apropriação da língua indígena e sua centralidade para a independência literária do país:

O conhecimento da língua indígena é o melhor critério para a nacionalidade da literatura. Ele nos dá não só o verdadeiro estilo, como as imagens poéticas do selvagem, os modos de seu pensamento, as tendências de seu espírito, e até as menores particularidades de sua vida. (ALENCAR, 1965, p. 195).

Para Alencar, a literatura brasileira, ainda em sua infância, caso quisesse diferenciar-se da literatura de sua antiga metrópole, deveria regressar a um tempo primitivo em que a língua indígena vivia em contato estreito com a natureza, sendo mais pura e espontânea. Esta é também uma perspectiva romântica, que opunha a poesia da natureza à poesia da cultura, afirmando ser aquela mais verdadeira, pois resultava da expressão interior e sincera do artista (ABRAMS, 2010).

Nas reflexões que amparam Iracema, José de Alencar representou o indígena como esse homem natural e propôs servir-se de sua língua na constituição de uma literatura nacional. A língua indígena, contudo, a ser incorporada à literatura, era aquela anterior à colonização. Realizando um apagamento de todas as línguas indígenas faladas em seu presente, Alencar deu um salto até um passado remoto, figurado como um lugar de origem, berço da nacionalidade.

Em sua pesquisa linguística relacionada aos indígenas, o romancista referenciou-se nos cronistas do século XVI e XVII, como Gabriel Soares de Souza, e em muitos pesquisadores contemporâneos para os quais as pesquisas da língua indígena se tornaram uma sociabilidade típica das elites letradas. A independência política trouxe sensível valorização dos vocábulos indígenas, pois eles significavam um legítimo sentimento de amor à terra. Também abundavam os dicionários de vocábulos indígenas, bem como artigos em jornais letrados e científicos que tinham como finalidade demonstrar a origem de determinadas palavras indígenas, sobretudo aquelas que deram nome às províncias e aos povoados. As plantas, os rios e os animais, cujos nomes eram indígenas, também se prestavam ao diletantismo dos escritores pós-independência, para quem tais estudos representavam sincero sentimento de amor à pátria. O próprio Alencar cita alguns desses autores, entre eles, Senador Pompeu, Ayres de Casal e von Martius. O conhecimento da etimologia das palavras indígenas era visto com bons olhos pelos escritores da época, pois era também um sinal de erudição, que se coadunava bem com a cultura bacharelesca do século XIX.

Alencar serviu-se largamente da língua indígena. Ele retirou dela, sobretudo, vocábulos, traduzindo-os, e integrou-os em sua narrativa, constituindo um enredo basicamente ocidental. Nem a forma como as línguas indígenas foram efetivamente incorporadas à fala americana, em um presente transculturado e heterogêneo, muito menos as variações linguísticas resultantes da apropriação que os indígenas fizeram da língua portuguesa interessavam ao seu projeto elitista e ocidentalizante.

O autor, à sua época, porém, formulou uma proposta original sobre o aproveitamento da língua indígena na narrativa nacional. Em sua Carta a Dr. Jaguaribe, o posfácio de Iracema, o romancista questionou o uso excessivo de vocábulos indígenas pelos escritores de sua época:

Muitas pecavam pelo abuso dos termos indígenas acumulados uns sobre outros, o que não só quebrava a harmonia da língua portuguesa, como perturbava a inteligência do texto. Outras eram primorosas no estilo e ricas de belas imagens; porém certa rudez ingênua de pensamento e expressão, que devia ser a linguagem dos indígenas, não se encontrava ali. (ALENCAR, 1965, p. 194) 
Esse mesmo questionamento já fora lançado em 1856, em sua Carta sobre a Confederação dos Tamoios. Incomodavam José de Alencar a linguagem rebuscada e o formalismo clássico com que Gonçalves de Magalhães traduzira a língua dos índios e a incorporara ao seu poema épico. Mesmo Gonçalves Dias, “poeta nacional por excelência”, era visto com ressalva, porque "[...] os selvagens do seu poema falam uma linguagem clássica [...]”, “[...] eles exprimem ideais próprias do homem civilizado, e que não é verossímil tivessem no estado da natureza” (ALENCAR, 1965, p. 195).

A preocupação do romancista parece ter sido com a narrativa moderna, que era distinta dos gêneros literários do passado. Alencar, inclusive, havia iniciado um poema épico, mas o deixou pelo meio do caminho (RIBEIRO, 2011). O modo como o autor narrou a saga dos indígenas, por meio do gênero romance, foi realmente original na sua época. Tais reflexóes alencarianas reiteraram sua condição de escritor renomado, cujas narrativas estavam em intenso diálogo com um público leitor. As questões desenvolvidas por Alencar, certamente, não estavam no horizonte de Gonçalves Magalhães, para quem o diálogo com um público leitor urbano, moderno, civilizado, não parecia exercer qualquer pressão sobre a criação artística. Vejamos essas esclarecedoras palavras de Alencar:

Um dia, porém, fatigado da constante e aturada meditação ou análise para descobrir a etimologia de algum vocábulo, assaltou-me um receio. Todo este improbo trabalho que as vezes custava uma só palavra, me seria levado à conta? Saberiam que esse escropulo d'ouro fino, tinha sido desentranhado da profunda camada, onde dorme uma raça extinta? Ou pensariam que fora achado na superfície e trazido ao vento da fácil inspiração? E sobre esse, logo outro receio. A imagem ou pensamento com tanta fadiga esmerilhados seriam apreciados em seu justo valor, pela maioria dos leitores? Não os julgariam inferiores a qualquer das imagens em voga, usadas na literatura moderna? (ALENCAR, 1965, p. 196)

Alencar, portanto, manejou com grande liberdade os termos indígenas em Iracema, o que demonstra grande consciência da constituição de uma língua literária para o Brasil. Em alguns casos, ele não só traduziu livremente alguns vocábulos indígenas, mas, com base neles, criou expressões e palavras. Como bem salientou, a ele interessavam a sonoridade da frase, a cor, o movimento da narrativa, que, de alguma forma, correspondessem aos anseios do leitor moderno (PELOGGIO, 2006). Nisso foi muito feliz, pois Iracema representou um sucesso de público, com duas edições vindas a lume com o autor ainda em vida.

Ainda conforme o trecho acima, a língua indígena que a literatura deveria aproveitar para a narrativa nacional foi extinta junto com os próprios indígenas. O escritor nacional deveria, ante esse fato, fazer uma regressão até o momento em que ela foi pura e singela. Articulada nesse tempo arcaico, a língua indígena era vista como estática e sem história. Com efeito, nesse prefácio, Alencar deu muito mais importância à natureza do que à cultura como fator transformador da língua. A língua brasileira nasceu do encontro da cultura do povo invasor com a natureza tropical, e nesta estavam incluídos os índios.

A escolha de uma língua indígena situada em um passado distante e proveniente de uma "raça extinta" coadunava-se com o pensamento das elites imperiais relativo aos indígenas. A própria ideia de que os índios já estavam extintos justificou, principalmente após a Lei de Terras, em 1850, o contínuo apossamentos de suas terras pelos grandes proprietários. Como a lei definia que, onde houvesse aldeamentos, vilas de índios ou mesmo a presença comprovada de comunidades indígenas, as terras deveriam ser consideradas propriedades destes, o argumento mais recorrente 
das elites era o de que simplesmente nas terras não existiam índios. As polêmicas em torno da existência ou não de índios, e mesmo os fatores culturais que o caracterizariam, atravessou quase todo o século XIX, sendo que a ideia de que eles eram uma raça extinta representou uma vitória dos setores colonialistas nacionais (VALE, 2009; OLIVEIRA, 2009).

Por outro prisma, a ideia do indígena como "raça extinta" está em sintonia com outra: a noção dos indígenas como degenerados. Conforme o imaginário corrente entre os escritores e romancistas do período, os índios haviam sido, em um período anterior à colonização, um povo nobre, honrado e guerreiro. A integração destes à colonização causou uma degradação em seus costumes. Deste modo, aqueles que ainda existiam no presente pouco se prestavam a uma elaboração imaginária da escrita indianista, que se centrou na imagem ideal daqueles índios distantes do tempo das narrativas nacionais (DAHER, 2012).

\section{A literatura e a língua falada pelo povo}

Depois de Iracema, as inúmeras polêmicas linguísticas nas quais José de Alencar se viu envolvido tinham como cerne a defesa do português como língua dinâmica, que se modifica e se adapta em novos ambientes e configuraçôes histórico-sociais. Esse era, fundamentalmente, seu principal argumento em defesa da variação da língua portuguesa falada no Brasil. O autor argumentou que a língua da literatura brasileira, caso quisesse se diferenciar da língua portuguesa, deveria partir da língua historicamente formada e ambientada nos trópicos. Como até a independência política não se cogitava sobre escrever que não fosse com base nas normas gramaticais e linguísticas de Portugal e os escritores brasileiros pagavam "tributo à imitação”, Alencar propôs investigar a língua falada pelo povo e nela se basear para a constituição da literatura nacional. Ele foi, portanto, um militante na defesa de um português mais fluído, mais sonoro, que imitasse a "fala americana". É nesse ponto que reside a importância do estudo da cultura do povo. A poesia popular tem sua importância porque, segundo Alencar:

[...] nós, escritores nacionais, se quisermos ser entendidos de nosso povo, havemos de falar-lhe em sua língua, com os termos e locuções que ele entende, e que lhe traduz os usos e sentimentos. Não é somente no vocabulário, mas também na sintaxe da língua, que o nosso povo exerce o seu inauferível direito de imprimir o cunho de sua individualidade, abrasileirando o instrumento das ideais. (ALENCAR, 1960, p. 966)

Assim sendo, a linguagem popular, na compreensão histórica de José de Alencar, passou a ser o elemento basilar da constituição da individualidade linguística nacional. $\mathrm{Na}$ introdução de seu romance Sonbos D'Ouro (1872), intitulado Benção paterna, ele já havia justificado a centralidade do estudo da fala do povo para a nacionalização da língua. Percebendo-se em um contexto de intenso influxo da civilização, em que o país era perpassado por muitas influências externas, Alencar viu o povo como um repositório de uma língua que progrediu em solo brasileiro, e nele passou por longa aclimatação. Como pensava, o povo, diferente dos letrados, estava mais enraizado na natureza brasílica. Sofreu, por conta disso, um longo processo de adaptação, que tornou a sua língua diferente da língua portuguesa. José de Alencar criou, basicamente, uma oposição entre uma língua historicamente formada no Brasil e as diversas línguas que "invadiam” o território brasileiro, 
com especial destaque para os afrancesamentos. Na citação a seguir, o romancista evidencia uma oposição entre as influências estrangeiras e uma língua, por assim dizer, histórica. Preocupava-o a maneira como devem ser mediadas na formação de uma literatura nacional:

Onde não se propaga com rapidez, a luz da civilização, que de repente cambia a cor local, encontra-se ainda em sua pureza original, sem mescla, esse viver singelo de nossos pais, tradiçôes, costumes e linguagem, com um sainete todo brasileiro. Ha, não somente no país, como nas grandes cidades, até mesmo na corte, desses recantos, que guardam intacto, ou quase, o passado [...]. É o efeito da transição que se opera; e também do amálgama de elementos diversos. A importação continua de ideias e costumes estranhos, que dia por dia nos trazem todos os povos do mundo, devem por força de comover uma sociedade nascente, naturalmente inclinada a receber o influxo de mais adiantada civilização. Os povos têm, na virilidade, um eu próprio, que resiste ao prurido da imitação; por isso na Europa, sem embargo da influência que sucessivamente exerceram algumas nações, destacam-se ali os caracteres bem acentuados de cada raça e de cada família. Não assim os povos são feitos; estes tendem como a criança ao arremedo; copiam tudo; aceitam o bom e o mal, o belo e o ridículo; para formarem o amálgama indigesto, limo de que deve sair mais tarde uma individualidade robusta. (ALENCAR, 1872, p. XIV)

Como expresso nessa passagem, o país era alvo de constante invasão das culturas estrangeiras. Em uma nação considerada ainda em sua infância, o desejo de imitar o que vinha de fora era justificável, sobretudo em se tratando da influência de países mais civilizados. Nas cidades e na Corte, onde o contato com a cultura "forasteira" era mais intenso, a sociedade brasileira ia perdendo ainda mais a sua tipicidade e ganhava uma "fisionomia indecisa, vaga e múltipla".

Segundo o autor, nos lugares mais distantes da civilização, no interior, nos sertões do país, a sociedade ainda mantinha traços culturais resultantes de uma formação mais antiga e tradicional. Nesse passado, marcado pelo consórcio dos portugueses, uma “raça ilustre”, e um povo guerreiro, os indígenas, consolidaram-se nas bases da cultura e da "língua brasileira". Nesse período "glorioso e viril", o país desenvolveu um "eu próprio" que o tornava resistente ao influxo da civilização e lhe possibilitava a cada dia se enriquecer "ao contato de outros povos". Em seu tempo, Alencar identificou ainda nas cidades, e até na corte, os "[...] recantos, que guardam intacto, ou quase, o passado [...]". A nacionalidade brasileira residia exatamente nesses redutos, pois lá "a cor local” “[...] encontra-se ainda em sua pureza original, sem mescla” (ALENCAR, 1872, p. XIII).

O escritor, portanto, percebia a civilização como um fator dissolvente das particularidades nacionais. À medida que ela avançava, ia apagando o que as sociedades tinham de original e típico. A garantia de que não haveria total dissolução era dada pelas formaçôes históricas mais antigas, tradicionais, que se desenvolveram e se consolidaram em terras brasileiras, com o destaque para a língua, pois seria ela que subsidiaria a constituição das literaturas nacionais. Essa língua, aquela "falada pelo povo", propiciaria ao escritor encontrar os vocábulos, as locuções e a sintaxe que serviriam de baliza para a constituição de uma literatura original e diversa da portuguesa.

\section{Duas faces da mesma moeda: o escritor como colonizador}

Apesar das propostas linguísticas diferentes, expressas em $O$ nosso cancioneiro e Iracema, são notórios nos dois escritos posicionamentos muito próximos de Alencar a respeito da língua indígena 
e da portuguesa falada no Brasil. Esta última aclimatou-se na natureza brasílica, o que ensejou uma variação linguística que a tornou diferente da língua matriz. Com respeito da segunda, além de ser vista como estática, o escritor deveria realizar uma depuração e dela retirar o que fosse digno de figurar como literatura. Escreveu Alencar:

Sem dúvida que o poeta brasileiro tem de traduzir em sua língua as ideias, embora rudes e grosseiras, dos índios; mas nessa tradução está a grande dificuldade; é preciso que a língua civilizada se molde quanto possa à singeleza primitiva da língua bárbara; e não represente as imagens e pensamentos indígenas senão por termos e frases que ao leitor pareçam naturais na boca do selvagem. (ALENCAR, 1965, p. 195)

A ambiguidade é evidente. Para Alencar, a língua indígena era rude, grosseira e bárbara. Era dotada, entretanto, de certa singeleza primitiva. Cabia ao escritor selecionar aqueles elementos linguísticos que cunhassem a individualidade nacional. Eles contribuiriam para tornar o português uma língua mais expressiva, mais sonora e com módulos mais suaves.

O predomínio da língua colonizadora, “civilizada” e erudita sobre as línguas indígenas e a língua falada pelo povo é quase completo. Isso fica claro no posfácio de Iracema, no qual polemiza com Pinheiro Chagas. O autor português acusava-o da pretensão de inventar novo idioma, já que isso não era tarefa do escritor, mas do povo. Alencar ironizou, respondendo: "Mas em vez de atribuir-nos a nós escritores essa revolução filológica, devia o Sr. Pinheiro Chagas, para ser coerente com sua teoria, buscar o germe dela e seu fomento, no falar do povo, esse 'ignorante sublime' como lhe chamou” (ALENCAR, 1965, p. 195). O romancista, nesse sentido, salientou o papel do escritor em "talhar" e "limar" o "grosseiro dialeto do vulgo", do "povo, rude e incoerente" (ALENCAR, 1965, p. 169). Num longo trecho de Benção Paterna, vê-se com mais clareza a tarefa que Alencar incumbiu ao escritor de, por assim dizer, civilizar as línguas do povo, seja este o indígena, o português ou o mestiço:

Sobretudo compreendam os críticos a missão dos poetas, escritores e artistas, nesse período especial e ambíguo da formação de uma nacionalidade. São estes os operários incumbidos de polir o talhe e as feições da individualidade que se vai esboçando no viver do povo. Palavra que inventa a multidão, inovação que adota o uso, caprichos que surgem no espírito do idiota inspirado; tudo isto lança o poeta no seu cadinho, para escoimá-lo das fezes, que porventura lhe ficaram do chão onde esteve, e apurar o ouro fino. E de quanta valia não é o modesto serviço de desbastar o idioma novo das impurezas que lhe ficaram na refusão do idioma velho com outras línguas? Ele prepara a matéria, bronze ou mármore, para os grandes escultores da palavra que erigem os monumentos literários da pátria. (ALENCAR, 1872, p. XVI)

Assim, o escritor se colocou perante uma diversidade linguística, que incluía, além da língua portuguesa, as línguas indígenas, africanas e as resultantes da "refusão do idioma velho com outras línguas", que Alencar tratou como impureza. Na percepção de Alencar, esse "cadinho" linguístico representava uma barbaria. Nas palavras de Júlio Ramos, "[...] escrever, nesse mundo, era dar forma a esse mundo modernizador, era civilizar, ordenar o sem sentido da barbárie americana” (RAMOS, 2008, p. 28).

Portanto, a tarefa do escritor era basicamente civilizadora, do ponto de vista da língua. A tópica romântica da decadência era ratificada por Alencar em sua concepção de um tempo presente 
amorfo e caótico. Ante tal concepção, seu horizonte de expectativas foi o delineamento de uma literatura e uma língua plenamente formadas em um futuro íntegro. A língua literária era o meio que o escritor possuía em sua tarefa de, a um só tempo, integrar o Brasil ao "influxo da civilização" e evitar que este perdesse as peculiaridades culturais, como uma nação em decurso de formação.

Ainda no pós-escrito de Iracema, Alencar retrucou Pinheiro Chagas, que salientou a transformação pela qual passava o português no Brasil como uma decadência. Segundo Alencar, o futuro decidiria se tais transformações representariam uma decadência ou uma florescência. E conclui: “[...] sempre direi que seria uma aberração de todas as leis morais que a pujante civilização brasileira, com todos os elementos de força e grandeza, não aperfeiçoasse o instrumento das ideias, a língua” (ALENCAR, 1965, p. 171).

A ênfase na identidade da língua com a nação foi concomitante à consolidação do Estado brasileiro. Foi posteriormente à independência política que os escritores começaram a se questionar sobre qual língua corresponderia à nação que estava sendo formada. Segundo Mignolo, de forma geral, "[...] as línguas nacionais surgiram em cumplicidade com o Estado e com as instituiçóes que regulavam os usos e abusos da língua” (MIGNOLO, 2003, p. 345). A sintonia das elites locais com o pensamento civilizador ocidental levou-as a definirem-se pela língua do colonizador e torná-la a língua oficial do Estado nacional nascente. Tal política da língua era condizente com uma ideologia do nacional que considerava a língua de matriz europeia superior às outras línguas do território nacional. A consolidação da língua portuguesa como código nacional pressupunha um exercício do poder de imposição da língua das elites nacionais sobre as outras línguas. Nesse sentido, a língua era mais um dos elementos de dominação e de exclusão política, econômica e social. A língua, portanto, tinha o poder de "[...] atuar sobre as conquistas geográficas como força unificadora” (MIGNOLO, 2003, p. 350).

Os inúmeros estudos sobre as línguas indígenas (KADAMA, 2009), tidas como um exotismo e pensadas como uma rigidez, indicavam um projeto nacionalizante que segregava tais línguas a um isolamento ou as incorporava de forma esquizofrênica. Em Iracema, essa operação de tradução redutora dos sentidos e da cosmovisão da língua indígena fica bem evidente. O esforço de Alencar era o de encontrar uma correspondência na língua portuguesa para termos presentes na fala indígena. Essa "tradução" deslocava os vocábulos de seu contexto linguístico, em que o significado não possuía tanta distância do significante, atribuindo a estes um sentido que pouco se aproxima da cosmovisão dos povos nativos; desterritorializa-os, portanto.

A língua indígena foi utilizada como "matéria-prima" da narrativa nacional, sendo a transculturação narrativa praticamente nula. ${ }^{6}$ Segundo Ángel Rama, tais métodos de processar a língua e a cultura indígena fazem parte do horizonte romântico burguês, baseado em uma ideia de representatividade e originalidade de nação. Nesse horizonte, são estabelecidos lugares distintos para as culturas locais e a cultura ocidental europeia. As primeiras, das quais procurou se diferenciar o escritor, são situadas em plano inferior, daí sua qualificação como rústica e primitiva, simples e ingênua. Essas também não são vistas como passíveis de mobilidade e transformação, sendo classificadas como línguas mortas ou extintas.

Por outro lado, José de Alencar, considerava que o português se abrasileirou por intermédio de uma adaptação ao território, percebendo, assim, a língua portuguesa em seu movimento e transformação. Numa perspectiva semelhante à que tinha das línguas indígenas, Alencar via com ressalva a língua portuguesa falada no Brasil. A língua falada, efetivamente transculturada, pois decorrente de um longo contato entre o colonizador, os indígenas e afrodescendentes, não 
deveria ser considerada a língua literária e culta. De um lado, a literatura nacional, culta e civilizada, de outro, as línguas e literatura populares, típicas e exóticas. As línguas e literaturas populares, portanto, são nacionais, mas não eram consideradas por Alencar como literatura. Desta forma, para Alencar, tanto a língua indígena como a língua falada pelo povo deveriam passar por uma depuração a fim de se tornarem literatura.

\section{Considerações finais}

De acordo com Mignolo, o território é um espaço de "interação de pessoas entre si e com o mundo". Nesse sentido, pode-se dizer que a ideia de nação expressa em José de Alencar, que ligava língua e literatura ao território nacional, atribuindo-lhe identidade única, portadora de uma língua comum, significava uma desterritorialização das línguas indígenas e locais (MIGNOLO, 2003, p. 366). A representação escrita das culturas locais e indígenas na América Latina opera, portanto, o que Mignolo denominou “[...] falas fora do lugar”. Nesse sentido, só a escrita possibilitaria criar fixidez e padronização da fala que é, por natureza, móvel, inconstante e viva, tendo a função de organizar e sistematizar o caos da realidade americana, como pensado pela maior parte dos escritores.

O estudo das línguas e dos costumes indígenas tornou-se muito comum entre os intelectuais brasileiros da época. Em nenhum momento, entretanto, esses escritores cogitavam a possibilidade de quaisquer dessas línguas se tornarem a língua oficial e administrativa do Brasil. Supondo que, em breve, os índios estariam dissolvidos na nação brasileira, imaginavam também que suas línguas e seus costumes estariam fadados a desaparecer. Os índios eram vistos com curiosidade, exotismo e certa nostalgia. Nessa perspectiva, se poderia contemplar a "beleza do morto" (CERTEAU, 1995). O discurso alencariano realizou uma operação que era ao mesmo tempo de apropriação e de exclusão. Alencar apropriou-se das culturas locais e indígenas com o objetivo de criar certa legitimidade aos seus projetos de elaboração cultural brasileira, que exigiam uma definição do que seria o povo formador da nação emergente. Ao integrá-las, porém, Alencar o fez de forma que estas perdessem toda a dinâmica histórica e fossem vistas de maneira harmoniosa, elidindo os conflitos em torno da imposição da língua colonizadora sobre as outras línguas. Integrou, portanto, as culturas indígenas ao discurso nacional e relegou-as a um horizonte "calmo e tranquilizador", do ponto de vista de uma perspectiva que classificava, descrevia e segregava, como bem refletiu Michel de Certeau, quanto à apropriação do popular pelos letrados (CERTEAU, 1995).

Em razão do pouco índice de alfabetização e da existência de muitas comunidades indígenas isoladas da civilização, os projetos de unificação nacional passaram ao largo de parte significativa dessa população. Essas comunidades não seriam um incômodo, até seus territórios tornarem-se “necessários” ao progresso do país. Caso a civilização avançasse, já que um dos princípios das naçôes era ser expansiva, as comunidades deveriam se submeter aos novos padróes culturais modernos. Essas últimas tiveram que se adequar ou correr o risco de desaparecerem.

As populações indígenas já haviam sido em parte desterritorializadas pelo processo de colonização. Os intensos deslocamentos das populaçôes nativas, escravizadas ou confinadas nos aldeamentos, que os colonizadores denominavam muito sugestivamente de reduçôes, acarretou uma fissura na relação que a linguagem estabelecia com o lugar. Os indígenas foram expulsos de seus territórios, ou mesmo capturados e aldeados. Nos aldeamentos, tiveram que adquirir um novo modo de vida e, consequentemente, uma nova língua. 
No concernente às comunidades afrodescendentes não foi muito diferente. Elas foram integradas à língua e à cultura nacional por processos violentos, que causaram significativo apagamento de suas línguas e de suas culturas. E, ainda que sejam identificados traços miscigenados na cultura brasileira, é inegável o grande predomínio da cultura ocidental colonialista. Afinal a "língua brasileira” que subsiste é, com algumas pequenas variações e alguns vocábulos, a língua portuguesa.

\section{Referências}

ABRAMS, Meyer Howard. O espelho e a lâmpada. São Paulo: Editora da UNESP, 2010.

ABREU, Mirhiane Mendes de. Ao pé da página: a dupla narrativa de José de Alencar. Campinas: Tese de Doutorado, IEL/UNICAMP, 2003.

ALENCAR, José de. Benção paterna. In: ALENCAR, José de. Sonhos d'Ouro. v.1. Rio de Janeiro: B. L. Garnier, 1872.

ALENCAR, José de. Iracema: lenda do Ceará. Rio de Janeiro: Typ. De Vianna e Filhos, 1965.

ALENCAR, José de. O nosso cancioneiro. In: ALENCAR, José de. Obra completa. v. IV. Rio de Janeiro: Aguilar, 1960, p. 963-982.

ALONSO, Ângela. Ideias em movimento: a geração de 1870 na crise do Brasil Império. São Paulo: Paz \& Terra, 2002.

ANDERSON, Benedict. Comunidades imaginadas: reflexões sobre a origem e difusão do nacionalismo. São Paulo: Cia das Letras, 2008.

BOECHAT, Maria Cecília. Paraísos artificiais: o romantismo de Alencar e sua recepção crítica. Belo Horizonte: Ed. UFMG; UFMG, 2003.

BORGES, Valdeci Rezende. Manuel Pinheiro Chagas leitor crítico de José de Alencar: a censura e a resposta. Intellèctus, ano IX, n. 2, 2010.

BORGES, Valdeci Rezende. Cultura, natureza e história na invenção alencariana de uma identidade na nação brasileira. Revista Brasileira de História, São Paulo, v. 26, n. 51, p. 89-114, 2006.

BOSI, Alfredo. Dialética da colonização. São Paulo: Cia das Letras, 1992.

CAMPOS, Haroldo de. Iracema: uma arqueologia de vanguarda. Revista USP, São Paulo, n. 5, p. 67-74, mar./ abr./maio 1990.

CANDIDO, Antonio. Formação da literatura brasileira. v. 1 e 2. Rio de Janeiro; Belo Horizonte: Editora Itatiaia, 1997.

CANDIDO, Antonio. Brasil: nações imaginadas. In: CANDIDO, Antonio. Pontos e Bordados: Escritos de História e Política. Belo Horizonte: Editora da UFMG, 1998. p. 233-268

CARVALHO, José Murilo de. Brasil: nações imaginadas. In: CARVALHO, José Murilo de. Pontos e Bordados: Escritos de História e Política. Belo Horizonte: Editora da UFMG, 1998. p. 233-268.

CERTEAU, Michel de. A beleza do morto. In: CERTEAU, Michel de. A cultura no plural. Campinas: Papirus, 1995. p. 55-85.

CHAGAS, Pinheiro. Literatura brasileira - José de Alencar. In: CHAGAS, Pinheiro. Iracema: lenda do Ceará. Rio de Janeiro: José Olympio, 1965. (Edição do centenário de Iracema).

COLETTI, Vittorio. A padronização da linguagem: o caso italiano. In: MORETTI, Franco. A cultura do romance. São Paulo: Cosac Naify, 2009. p. 375-458.

CORNEJO POLAR, Antônio. O Condor voa: literatura e cultura latino-americanas. Belo Horizonte: Ed. da UFMG, 2000.

COSTA, Adriane A. Vidal. José Veríssimo: o sujeito e o espaço na construção da nação brasileira. Paralelo 20, Belo Horizonte, v. 2, p. 35-46, 2004. 
DAHER, Andrea. A oralidade perdida: ensaio de história das práticas letradas. Rio de Janeiro: Civilização Brasileira, 2012.

ELIAS, Norbert. O processo civilizador. v. 1. Rio de Janeiro: Zahar, 1992.

HOBSBAWN, Eric. Nações e nacionalismo de 1780: programa mito e realidade. Rio de Janeiro: Paz \& Terra, 1990.

KADAMA, Kaori. Os índios no Império do Brasil: etnografia do IHGB entre as décadas de 1840 e 1860 . Rio de Janeiro: Editora FIOCRUZ; São Paulo: EDUSP, 2009.

LIMA, Ivana Stolze. A língua brasileira e os sentidos de nacionalidade e mestiçagem no Império do Brasil. TOPOI, v. 4, n. 7, p. 334-356, jul./dez. 2003.

MIGNOLO, Walter D. História locais/projetos globais: colonialidade, saberes subalternos e pensamento liminar. Belo Horizonte: Editora da UFMG, 2003.

MORAIS PINTO, Maria Cecília. A vida selvagem: paralelo entre Chateaubriand e Alencar. São Paulo: Annablume, 1995.

NEVES, Lúcia Maria B. P. das; MACHADO, Humberto Fernandes. O Império do Brasil. Rio de Janeiro: Nova Fronteira, 1999.

OLIVEIRA. João Pacheco de. In: As mortes do indígena no Império do Brasil: o indianismo a formação da nacionalidade e seus esquecimentos. In: KNAUSS, Paulo; AZEVEDO, Cecília; ROLLEMBERG, Denise (org.). Cultura política, memória e historiografia. Rio de Janeiro: Editora FGV, 2009. p. 229-268.

PELOGGIO, Marcelo. José de Alencar e as visões do Brasil. Niterói. Tese (Doutorado) - Universidade Federal Fluminense - UFF, 2006.

PERRONE-MOYSÉS, Leila. Vire e mexe nacionalismo: paradoxos do nacionalismo literário. São Paulo: Cia das Letras, 2007.

RAMA, Ángel. Os processos de transculturação cultural na América Latina. In: AGUIAR, Flávio; GUARDINI, Sandra T. (org.). Ángel Rama: literatura e cultura na América Latina. São Paulo: Editora da Universidade de São Paulo, 2001. p. 209-238.

RAMOS, Júlio. Desencontros da modernidade na América Latina: literatura e política no século XIX. Belo Horizonte: Editora UFMG, 2008.

RIBEIRO, Cristina Betioli. Um Norte para o romance brasileiro: Franklin Távora entre os primeiros folcloristas. Tese (Doutorado) - IEL-UNICAMP, Campinas, 2008.

RIBEIRO, Maria Aparecida. Exílios de Iracema: da nova raça à diluição da identidade brasileira. Agália, n. 33-34, p. 199-206, 2. sem. 2005.

RIBEIRO, Maria Aparecida. Jakaré-Ouassou e a luta pela hegemonia literária. Máthesis, 6, 1997.

RIBEIRO, Maria Aparecida. Projeto e realização épica em José de Alencar. Hist. R., Goiânia, v.16, n. 1, jan./jun. 2011. SALIBA, Elias Thomé. Utopias românticas. São Paulo: Estação Liberdade, 2002.

SANTIAGO, Silviano. Vale quanto pesa: ensaios sobre questões político-culturais. Rio de Janeiro: Paz e Terra,1982. SOMMER, Doris. Ficções de fundação: os romances nacionais na América Latina. Belo Horizonte: Ed. UFMG, 2004.

VALE, Carlos Guilherme Octaviano do. Aldeamentos Indígenas no Ceará: revendo argumentos históricos sobre o desaparecimento étnico. In: PALITOT, Estevão Martinhs. Na Mata do sabiá: contribuições sobre a presença indígena no Ceará. Fortaleza: Secult: Museu do Ceará: IMOPEC, 2009. p. 106-154.

TRECEE, Dave. Exilados, aliados, rebeldes: o movimento indianista, a política indigenista e o estado-nação imperial. São Paulo: Nankin; Edusp, 2008.

WILLIAMS, Raymond. O campo e a cidade: na história e na literatura. São Paulo: Cia das Letras, 1989.

\section{Notas}

${ }^{1}$ Utiliza-se a expressão “íngua brasileira” entre aspas, pois o brasileiro não é bem uma língua distinta da língua portuguesa, mas uma variação desta. José de Alencar, por exemplo, referiu-se ao português falado no Brasil como um novo idioma. 
Como mostrou Ivana Stolze Lima, alguns escritores e críticos do Brasil referiam-se ao português falado no Brasil como uma nova língua (LIMA, 2003).

2 Ángel Rama (2001) realizou semelhante reflexão sobre as formas como as narrativas latino-americanas processaram a língua do povo.

${ }^{3}$ Nos anos de 1880, Silvio Romero denunciou esse sepulcral silêncio, mas a custo de considerar as línguas africanas bárbaras e incivilizadas. Com o Modernismo, o problema teve grande destaque e a fala dos africanos no Brasil foi incorporada como fator importante da língua. Gilberto Freire observava os costumes dos diminutivos e da fala meio amolengada como traços de uma herança africana que não nos deveria envergonhar.

${ }^{4}$ Segundo Elias, “[...] no topo, por quase toda a Alemanha, situavam-se os indivíduos ou grupos que falavam francês e decidiam a política. No outro lado, havia uma intelligentsia de fala alemã que de modo geral nenhuma influência exercia sobre fatos políticos. De suas fileiras saíram basicamente os homens por conta dos quais a Alemanha foi chamada terra dos poetas e pensadores. E deles, conceitos como Bildung e Kultur receberam seu cunho e substância especialmente alemães" (ELIAS, 1992, p. 33).

${ }^{5} \mathrm{O}$ conceito de transculturação narrativa é tomado de Ángel Rama (2001). 